NANAEKE

Indonesian Journal of Early Childhood Education

Volume 2, Nomor 2, Desember 2019

\title{
IMPLEMENTASI MANAJEMEN PESERTA DIDIK PADA SATUAN PAUD
}

\author{
Ade Agusriani \\ Jurusan Pendidikan Islam Anak Usia Dini \\ Fakultas Tarbiyah dan Keguruan, UIN Alauddin Makassar \\ E-mail: ade.agusriani@uin-alauddin.ac.id \\ Hading \\ Fakultas Tarbiyah dan Keguruan, UIN Alauddin Makassar \\ E-mail: hading@uin-alauddin.ac.id \\ Hilda Ayu Wahdaniah \\ Jurusan Pendidikan Islam Anak Usia Dini \\ Fakultas Tarbiyah dan Keguruan, UIN Alauddin Makassar \\ E-mail: hildaayuwahdaniah@gmail.com \\ Dila Rizki Amalia \\ Jurusan Pendidikan Islam Anak Usia Dini \\ Fakultas Tarbiyah dan Keguruan, UIN Alauddin Makassar \\ E-mail: dilarizkiamalia11@gmail.com \\ Siti Hardiyanti Syarif \\ Jurusan Pendidikan Islam Anak Usia Dini \\ Fakultas Tarbiyah dan Keguruan, UIN Alauddin Makassar \\ E-mail: antiihardiyanti20@gmail.com \\ Nur Ismi A. Arsyad \\ Jurusan Pendidikan Islam Anak Usia Dini \\ Fakultas Tarbiyah dan Keguruan, UIN Alauddin Makassar \\ E-mail: nurismiasryad47@gmail.com
}

\begin{abstract}
Abstrak
Penelitian ini bertujuan untuk mengetahui gambaran implementasi manajemen peserta didik di TK Pertiwi Malaka Jl. Massusungan DG Matutu Desa Malaka, Kec. Tondong Tallasa, Kab. Pangkep. Jenis penelitian yang di lakukan adalah penelitian deskriptif kualitatif dengan objek penelitian adalah seorang guru TK Pertiwi Malaka dengan teknik pengumpulan datamelalui observasi dan wawancara. Hasil penelitian menunjukkan bahwa TK Pertiwi Malaka telah memenuhi standar dalam manajemen peserta didik yaitu: a) Tahapan pertama perencanaan peserta didik dengan melakukan analisis kebutuhan peserta didik dengan mempertimbangkan rasio jumlah ruang kelas, jumlah guru dan murid. b) Kehadiran dan ketidak hadiran peserta didik disebut dengan istilah absensi disekolah. c) Pencatatan dan pelaporan peserta didik dapat dimulai dari anak masuk sekolah sampai anak lulus/tamat sekolah. d) Pelaksanaan tata tertib peserta didik yaitu pakaian seragam sekolah
\end{abstract}


sudah menjadi kewajiban bagi setiap peserta didik. e) Evaluasi kegiatan peserta didik dilakukan melalui beberapa cara yakni observasi, wawancara dan portofolio. f) Pembiayaan peserta didik. g) Kelulusan dan alumni peserta didik di buktikan dengan pemberian ijazah saat lulus.

Kata Kunci: Manajemen; Pendidikan Anak Usia Dini; Satuan PAUD

\begin{abstract}
This study aims to determine the description of the implementation of student management in TK Pertiwi Malaka Jl. Massusungan DG Matutu Desa Malaka, Kec. Tondong Tallasa, Kab. Pangkep This type of research is a qualitative descriptive study with the object of research is a kindergarten teacher Pertiwi Malacca with data collection techniques through observation and interviews. The results showed that TK Pertiwi Malaka had met the standards in student management, namely: a) The first stage of student planning by analyzing the needs of students taking into account the ratio of the number of classrooms, the number of teachers and students. $b)$ The presence and absence of students is referred to as school attendance. c) Recording and reporting of students can be started from children entering school until the children graduate/graduate from school. d) Implementation of the students' code of conduct ie school uniforms have become an obligation for every student. e) Evaluation of student activities is done in several ways namely observation, interviews and portfolios. f) Funding students. g) Graduation and alumni of students are proven by granting a diploma upon graduation.
\end{abstract}

Keywords: Management; Early childhood education programs; PAUD Unit

\title{
PENDAHULUAN
}

Pendidikan nasional merupakan pendidikan yang mendasari pancasila dan UndangUndang Dasar Negara 1945 yang mempunyai akar pada niai-nilai agama, kebudayaan nasioanl Indonesia dan mengikuti segala tuntunan perubahan zaman. Pendidikan adalah suatu usaha untuk mewujudkan suasana belajar dan segala proses pembelajaran agar seluruh peserta didik dapat aktif dalam mengembangkan potensinya seperti kekuatan spiritual keagamaan, pengendalian diri, kepribadian, kecerdasan serta keterampilan yang diperlukan oleh peserta didik.

Pendidikan anak usia dini (PAUD) diselenggarakan sebelum jenjang pendidikan dasar dan dapat diselenggarakan melalui jalur formal, nonformal dan informal. Pendidikan anak usia dini (PAUD) pada jalur formal berbentuk Taman Kanak-Kanak (TK), Raudatul Athfal (RA), sedangkan bentuk lain yang sederajat pendidikan anak usia dini. PAUD pada jalur pendidikan nonformal berbentuk kelompok bermain (KB), taman penitipan anak (TPA), dan pendidikan anak usia dini (PAUD) pada jalur pendidikan informal berbentuk pendidikan konseling (keluarga) atau pendidikan yang diselenggarakan oleh lingkungan

Pendidikan anak usia dini (PAUD) dalam Undang-undang RI No. 20 tahun 2003, pasal 1 ayat 14, “Pendidikan anak usia dini adalah suatu upaya pembinaan yang 
ditujukan kepada anak sejak lahir sampai dengan usia enam tahun yang dilakukan melalui pemberian rangsangan pendidikan untuk membantu pertumbuhan dan perkembangan jasmani dan rohani agar anak memiliki kesiapan dalam memasuki pendidikan lebih lanjut".

Secara umum kata "Manajemen" berasal dari bahasa Inggris (Management) dan dalam bahasa Prancis (Menagement) yang memiliki arti "Seni Melaksanakan" dan "Mengatur". Kata "Management" (Inggris) juga merupakan kata dasar dari istilah "To Manage” yang berarti “Mengelola, Mengatur atau Mengurus".Manajemen melingkupi dua kegiatan, yaitu kegiatan pikir (mind) dan kegiatan tingkah laku (action).Menurut Kamus Besar Bahasa Indonesia merupakan sumber daya secara efektif untuk mencapai sasaran. Sedangkan manajemen menurut istilah adalah proses mengoordinasikan aktivitas-aktivitas kerja sehingga dapat selesai secara efisien dan efektif melalui orang lain. (Lilis Sulastri, 2014). Dengan demikian manejemen merupakan upaya untuk mengatur dan mengelola aktivitas-aktivitas kerja agar terwujud suatu hal yang efektif dan efisien.

Berdasarkan hasil penelitian Annisa (2017) bahwa manajemen merupakan sebuah langkah-langkah ataupun cara dalam mengatur sesuatu agar apa yang diinginkan atau suatu hal yang ingin dicapai dapat berjalan dengan sebaik mungkin. Selanjutnya Suharni (2019) mengemukakan bahwa manajemen memiliki makna sebagai usaha mengelola, mengendalikan, dan mengarahkan berbagai sumber yang ada untuk mencapai tujuan yang di harapkan.

Pendidikan yang berkualitas menghasilkan peserta didik yang unggul dalam berbagai aspek perkembangan, agar potensi dan kemampuan masing-masing anak didik dapat diaktualisasikan dalam setiap kegiatan pembelajaran. Dalam dunia pendidikan juga dibutuhkan upaya manajemen yang dikenal dengan istilah manajemen pendidikan agar proses pendidikan dapat berjalan secara efektif dan efisien.

Salah satu hal yang menjadi fokus dalam manajemen pendidikan adalah manajemen peserta didik. Manajemen peserta didik merupakan suatu proses pelayanan, pengurusan atau pengelolaan semua kegiatan peserta didik mulai dari pendaftaran sampai dengan kelulusan peserta didik tersebut dari sebuah lembaga pendidikan berupa sekolah atau madrasah. (Muhammad Kristiawan, dkk, 2017).

Tujuan umum manajemen peserta didik adalah dapat mengatur segala bentuk kegiatan peserta didik, agar segala kegiatan dapat menunjang proses-proses dalam bentuk belajar mengajar disekolah. Agar segala proses tersebut mencapai tujuan yang diinginkan, belajar mengajar disekolah maupun lembaga-lembaga yang ada memberlakukan tata tertib dan peraturan sehingga tercapai tujuan sekolah dan pendidikan secara keseluruhan. (Suwardi dan Daryanto, 2017).

Adapun fungsi umum manajemen peserta didik adalah sebagai acuan bagi peserta didik untuk mengembangkan potensi diri seoptimal mungkin, baik yang berhubungan dengan invidual, sosial, kebutuhan dan potensi peserta didik

86 NANAEKE - Indonesian Journal of Early Childhood Education, Vol. 2, No. 2, Desember 2019 
Dalam manajemen peserta didik terdapat dua pendekatan yang digunakan, yaitu; pertama, pendekatan kuantitatif, yaitu lebih mengutamakan pada segi-segi administratif dan birokratif yang ada di lembaga pendidikan. Dan yang kedua, pendekatan kualitatif yaitu lebih diarahkan agar peserta didik senang.

Penelitian ini dilakukan agar sekolah atau lembaga-lembaga pendidikan anak usia dini jalur formal, non formal dan informal memahami manejemen peserta didik terkait a) perencanaan peserta didik. b) kehadiran dan ketidakhadiran peserta didik. c) pencatatan dan pelaporan peserta didik. d) pembinaan peserta didik. (e) Evaluasi kegiatan peserta didik, (f) Kelulusan dan alumni.

\section{METODE PENELITIAN}

Jenis penelitian ini merupakan penelitian deskriptif kualitatif.Penelitian deskriptif kualitatif merupakanrangkaian kegiatan untuk memperoleh data yang bersifat apa adanya tanpa ada dalam kondisi tertentu yang hasilnya lebih menekankan pada makna. Sumber data yang terdapat dalam penelitian ini yang juga sekaligus menjadi informan utama yaitu kepala sekolah dan salah satu guru di TK Pertiwi Malaka. Adapun pemilihan TK berdasarkan kriteria; (1) dapat diakses dengan mudah oleh peneliti, (2) Minimal berakreditasi B. Penelitian ini dilakukan dengan teknik pengumpulan data yang menggunakan wawancara terstruktur, dalam penelitian ini peneliti membuat daftar pertanyaan yang kemudian diajukan kepada responden.

\section{HASIL DAN PEMBAHASAN}

Hasil penelitian yang dilakukan dengan metode wawancara dan observasi di TK Pertiwi Malaka Kec Tondong Tallasa Kab Pangkep diperoleh jumlah guru dengan kualifikasi. Pada TK Pertiwi Malaka terdapat tiga pendidik, satu kepala sekolah dan dua guru kelas yang masing-masing memiliki gelar Sarjana. Adapun visi TK Pertwi Malaka yaitu menumbuh kembangkan anak usia dini agar menjadi siswa yang cermat yaitu cerdas, kreatif, beriman, dan hemat, siap memasuki pendidikan dasar. Misi TK Pertiwi Malaka yaitu: (1) Mengembangkan daya kreatif, kecerdasan dan kompetensi dasar melalui kegiatan pembelajarannya, (2) Memberi pembinaan kepada anak untuk melayani kebutuhan dan mengatasi permasalahannya sendiri, (3)Memberikan pendidikan budi pekerti yang dilandasi oleh nilai-nilai agama dan budaya, (4) Membiasakan anak untuk hidup hemat, (5) Membiasakan anak untuk bersikap santun dalam segala kegiatan, (6) Menyiapkan anak untuk siap memasuki pendidikan dasar.

TK Pertiwi Malaka mempunyai tujuan yaitu; (1) Mempersiapkan anak usia dini untuk memasuki pendidikan dasar dengan belajar sambil bermain, (2) Terwujudnya suasana TK yang kondusif dan administrasi yang transparan dan tertib, (3) Mengasuh dan membina peserta didik dengan penuh kasih sayang dan kesabaran, (4) Mengembangkan minat anak cerdas, kreatif, trampil, mandiri dan bermain. 
Manajemen peserta didik memiliki tujuh prinsip dasar yakni 1) penyelenggara dapat mengacu pada peraturan yang berlaku pada saat melakukan program yang dilaksanakan, 2) manajemen peserta didik dapat dilihat sebagai bagian dari keseluruhan manajemen sekolah, 3) semua bentuk kegiatan manajemen peserta didik harus mengacu pada misi pendidikan dalam rangka mendidik para peserta didik, 4) kegiatan manajemen peserta didik harus diupayakan untuk mempersatukan peserta didik yang mempunyai aneka ragam latar belakang dan punya banyak perbedaan. 5) kegiatan manajemen peserta didik harus dipandang sebagai upaya pembimbingan peserta didik, 6) kegiatan manajemen peserta didik harus mendorong kemandirian peserta didik, 7) kegiatan yang diberikan pada peserta didik harus fungsional bagi kehidupan peserta didik baik di sekolah atau di masyarakat (Badrudin, 2014).

Berdasarkan hasil observasi dan wawancara dengan subjek penelitian akan dibahas mengenai ruang lingkup pembahasan manajemen peserta didik yang terdiri dari:a) Perencanaan peserta didik, (b) pengelolaan kehadiran dan ketidakhadiran peserta didik, (c) Pencatatan dan pelaporan peserta didik, (d) pelaksanaan tata tertib peserta didik, (e) Evaluasi kegiatan peserta didik, (f) Kelulusan dan alumni.

\section{a. Perencanaan peserta didik}

Langkah pertama yang dilakukan oleh TK Pertiwi Malaka dalam perencanaan peserta didik hal yaitu dengan menganalisis jumlah peserta didik yang akan diterima melalui pertimbangan daya tampung dan jumlah ruang kelas yang tersedia, serta rasio jumlah guru dan muridnya.

Jumlah peserta didik yang direkrut di TK Pertiwi Malaka berdasarkan hasil wawancara yaitu sebanyak 33 siswa, kelas A sebanyak 22 siswa dan kelas B sebanyak 11 siswa. Setiap kelompok di tempatkan di 1 kelas dengan 1 orang guru yang berbeda.Tk Pertiwi Malaka tidak mempunyai guru pendamping dikarenakan TK Pertiwi Malaka hanya memiliki 2 orang guru saja, jadi dapat disimpulkan masingmasing guru bertanggungjawab mengelola satu kelas. Oleh karena itu sebaiknya pihak sekolah menambahkan dua guru pendamping agar proses pembelajaran dapat berjalan dengan efektif.

Yang kedua, yaitu proses penerimaan peserta didik. Penerimaan peserta didik di TK Pertiwi Malaka terbuka setiap waktu. Proses pendaftaran siswa baru masih bersifat on the spot (pendaftaran di kantor sekolah), belum dapat di akses secara online dikarenakan TK Pertiwi Malaka tidak memiliki akses jaringan internet karena letaknya yang berada jauh dari pusat perkotaan. Setiap orangtua siswa dapat mendaftarkan anaknya langsung ke TK Pertiwi Malaka yang terletak di Jl. Massusungan Dg Matutu, Desa Malaka, Kec. Tondong Tallasa, Kab. Pangkep.

TK Pertiwi Malaka tidak membentuk secara khusus panitia penerimaan peserta didik baru karena jumlah guru yang masih terbatas. Oleh karena itu, setiap guru wajib datang dan melaksanakan penerimaan peserta didik baru.

88 NANAEKE - Indonesian Journal of Early Childhood Education, Vol. 2, No. 2, Desember 2019 
Yang ketiga, yaitu masa orientasi peserta didik, peserta didik diperkenalkan lingkungan yang berada di TK Pertiwi Malaka serta diperkenalkan guru-guru dan stafstaf yang lainnya.

Keempat, yaitu pembagian kelas peserta didik. Dalam pembagian kelas para guru membagi kelompok ( kelas ) berdasarkan usia, 4-5 tahun kelompok A, 5-6 tahun kelompok B. Pengelompokkan tersebut berdasarkan karakteristik usia. Ali Imron (1995:75) mengemukakan bahwa pengelompokan berdasarkan karakteristik itu dimaksudkan agar mereka berada dalam ruang lingkup yang sama. Dalam kondisi yang sama dapat memudahkan pemberian layanan yang sama. Pengelompokkan siswa artinya agar pembelajaran dapat berjalan dengan lancar, tertib dan tujuantujuan pembelajaran dapat tercapai sesuai dengan apa yang telah diprogramkan.

Kelima, yaitu pencacatan dan pelaporan peserta didik di TK Pertiwi Malaka di mulai sejak awal terdaftar di sekolah sampai anak tersebut lulus.

\section{b. Mengatur kehadiran dan ketidakhadiran peserta didik}

Kehadiran dan ketidakhadiran peserta didik disebut dengan istilah absensi disekolah.Kehadiran dan keikutsertaan peserta didik secara fisik dan mental terhadap aktivitas sekolah pada jam-jam yang telah ditentukan oleh pihak sekolah tersebut.Sedangkan ketidakhadiran adalah ketiadaan partisipasi secara fisik oleh peserta didik terhadap kegitan-kegiatan sekolah.

Pada umumnya ketidakhadiran siswa dibagi menjadi tiga yaitu; (1) Alpa, (2) Sakit, (3) Izin. Pada dasarnya tingkat ketidakhadiran siswa menjadi tanggung jawab setiap guru yang pada saat itu mengajar di kelas tersebut Di TK Pertiwi Malaka kehadiran dan ketidakhadiran peserta didik dicatat oleh guru sesuai dengan pelaporan dari orangtua/wali peserta didik tersebut.

\section{c. Pencatatan dan pelaporan peserta didik}

Pencatatan dan pelaporan peserta didik dapat dimulai dari anak masuk sekolah sampai anak lulus/tamat dari sekolah tersebut.Tujuan dilakukannya pencatatan agar sekolah dapat bertanggung jawab terhadap peserta didik ketika lulus/tamat.Pelaporan bertujuan agar sekolah dapat melaporkan perkembangan anak kepada orangtua/wali pada saat peserta didik lulus/tamat.

Di TK Pertiwi Malaka bentuk pencatatan dan pelaporan peserta didik menggunakan buku yang berisi catatan tentang sikap dan perilaku peserta didik mulai dari awal masuk sekolah sampai dengan lulus/tamat.

\section{d. Pelaksanaan tata tertib peserta didik}

Setiap peserta didik memiliki kewajiban untuk mengenakan seragam sekolah sesuai dengan ketentuan pihak sekolah.Dari hasil observasi di TK Pertiwi Malaka dan hasil wawancara oleh salah satu guru mengatakan bahwa di TK Pertiwi Malaka mempunyai seragam khusus untuk peserta didik dan semua siswa telah mengenakan seragam tersebut pada hari sekolah. 
Dari segi kebersihan guru mewajibkan peserta didik setelah makan dan minum membuang sampah pada tempat yang telah disediakan. Adapun jam masuk pukul 08.00 dan jam pulang pukul 10.00, dan seluruh peserta didik wajib mengikuti aturan yang telah diberlakukan tersebut.

\section{e. Evaluasi kegiatan peserta didik}

Evaluasi secara umum dapat diartikan sebagai proses sistematis untuk menentukan nilai suatu (ketentuan, kegiatan, keputusan, unjuk kerja, proses, orang, objek dan yang lainnya) berdasarkan kriteria tertentu melalui penilaian. Dengan adanya evaluasi peserta didik dapat mengetahui sejauh mana keberhasilan yang telah di capai selama mengikuti pendidikan. Pada kondisi dimana siswa mendapatkan nilai yang memuaskan maka akan memberikan dampak berupa suatu reward, motivasi agar siswa dapat lebih meningkatkan prestasi dalam proses pembelajaran.

Di TK Pertiwi Malaka, evaluasi dilakukan setelah proses pembelajaran/kegiatan berlangsung, untuk penilain akhir guru mengumpulkan penilaian dari hasil yang dilakukan secara harian kemudian di rekap. Di TK pertiwi malaka guru tidak memberikan ujian akhir kepada anak-anak dan hanya melakukan pengayaan kepada anak yang belum cukup memenuhi indikator pencapaian perkembangan.

\section{f. Kelulusan dan alumni peserta didik}

Lembaga untuk satuan pendidikan (sekolah) adalah lulusan atau output standar kompetensi Lulusan untuk satuan pendidikan standar kompetensi lulusan digunakan sebagai pedoman penilaian dalam penentuan kelulusan peserta didik dari satuan pendidikan.

Dari hasil peneletian Di TK Pertiwi Malaka anak-anak yang telah menyelesaikan semester di kelompok A dan dua semester di kelompok B di tandai dengan pernyataan pengeluaran ijazah yang dikeluarkan oleh dinas pendidikan kota Pangkep dan namanya akan terdaftar di buku alumni pada sekolah tersebut.

\section{KESIMPULAN}

Manajemen peserta didik merupakan sebuah langkah yang dapat diatur dalam mencapai suatu hal yang diinginkan agar dapat berjalan dengan lancar sesuai apa yang telah diprogramkan, serta menghasilkan produk sesuai dengan harapan, kunci dari manajemen peserta didik ini adalah seorang guru yang dapat menilai peserta didiknya dari ia masuk sekolah hingga menjadi alumni. Bagaimana seorang guru mampu memantau aktivitas serta kegiatan anak diluar maupun didalam sekolah yang akan mereka laporkan pada saat kelulusan.

Dari hasil penelitian di TK Pertiwi Malakadengan menggunakan metode observasi dan wawancara oleh salah satu guru, dapat dilihat bahwa mulai dari pendaftaran peserta didik hingga kelulusan/alumni para pengelola dan guru dapat 
memenuhi semua ruang lingkup manajemen peserta didik mulai dari: (a) Perencanaan peserta didik, (b) Mengatur kehadiran dan ketidakhadiran peserta didik, (c) Pencatatan dan pelaporan peserta didik, (d) perencanaan tata tertib peserta didik, (e)Eevaluasi kegiatan peserta didik, (f) Kelulusan dan alumni peserta didik.

\section{DAFTAR PUSTAKA}

Alwi, Besse Marjani., Ramadani, Suci., Suhanir., Safira, Zulaika., \& Herma, Tendri. (2018). Manajemen Peserta Didik Pada Taman Pendidikan Anak Usia Dini Do'a Ibu. Nanaeke: Indonesian Journal Of Early Childhood Education, 1(1): 53-62.

Annas, Annis Nuraisyah. (2017). Manajemen Peserta Didik Berbasis Kecerdasan Spiritul Pendidikan. Jurnal Manajemen Pendidikan Islam, 5 (2): 132-142.

Badrudin.(2014). Manajemen Peserta Didik. Jakarta: PT Indeks.

Hardianti, Leli Siti. (2017). Pengaruh Pelaksanaan Tata Tertib Sekolah Terhadap Kedisplinan Belajar Siswa (Penelitian Deskriftif Analisis di SDN Sukakarya II Kecamatan samarang Kabupaten Garut). Journal Pendidikan Uniga, 2 (1): 1-8.

Junaidi. (2015). Pelaksanaan Manajemen Peserta Didik Pada Man Beringin Kota Sawahlunto. Jurnal Manajemen Pendidikan, 3(1): 37-46.

Mahirah, B. (2017). Evaluasi Belajar Peserta Didik. Jurnal Idaarah , 1 (2): 257-267.

Kristiawan, Muhammad., Safitri, Diana., Lestari, Rena. (2017). Manajemen Pendidikan. Sleman: Penerbit Deepublish.

Noor, Fu'ad, Arif. (2015). Manajemen Peserta Didik Raudlatul Athfal (RA). Jurnal Komunikasi dan Pendidikan Islam, 4 (2): 129-164.

Nuryanta, Nanang. (2015). Reorientasi Pendidikan Nasional Dalam Menyiapkan Daya Saing Bangsa. Jurnal el-Tarbawi. 8 (2): 111-130.

Petunjuk Teknis Penyelenggaraan Taman Kanak-Kanak.

Suharni. (2019). Manajemen Pendidikan Anak Usia Dini Pada PAUD Bintang Rabbani Pekanbaru. Jurnal IImiah Potensia, 9 (1): 1-5.

Sulastri, Lilis. (2014). Manajemen. Bandung: La Goods Publishing.

Suwardi, Daryanto. (2017). Manjemen Peserta Didik.Yogyakarta: Gava Media.

Suminar, Wahyu. (2018). Manajemen Peserta Didik Untuk Meningkatkan Prestasi Siswa Pada Madrasah Aliyah Negeril (MAN) Pacitan. Jurnal Muslim Heritage, 2(2): 389-406. 